
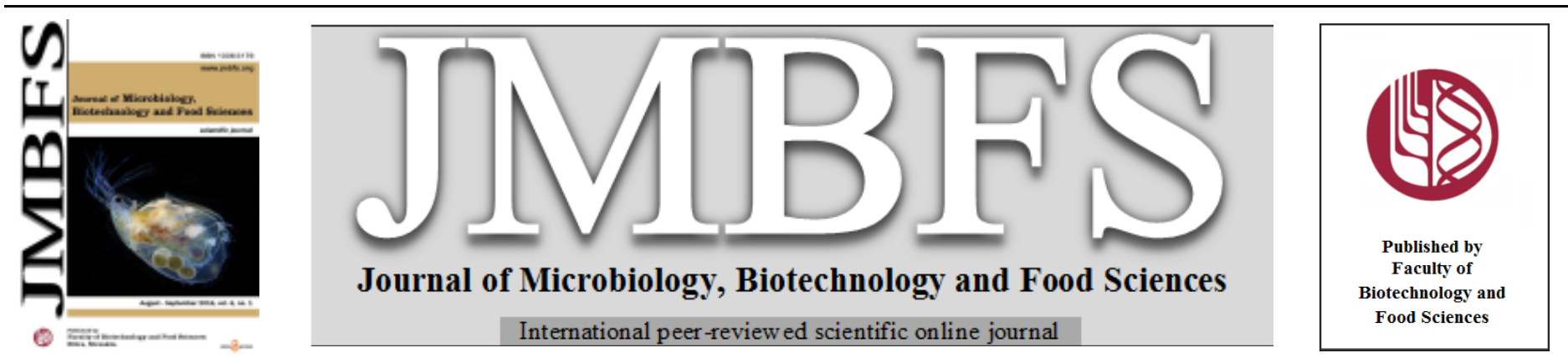

\title{
DIVERSITY ASSESSMENT AND EPS PRODUCTION POTENTIAL OF CULTIVABLE BACTERIA FROM THE SAMPLES OF COASTAL SITE OF ALANG
}

\author{
Kinjal H. Upadhyay, Avni M. Vaishnav, Devayani R. Tipre, Shailesh R Dave* \\ Address(es): Prof. Shailesh R. Dave, \\ Department of Microbiology and Biotechnology, School of Sciences, Gujarat University, Ahmedabad 380009, India.
}

*Corresponding author: shaileshrdave@yahoo.co.in

doi: 10.15414/jmbfs.2016.6.1.661-666

\section{ARTICLE INFO}

Received 19. 9. 2015

Revised 3. 3. 2016

Accepted 21.3. 2016

Published 1. 8. 2016

Regular article

open $\partial_{\text {Access }}$

\begin{abstract}
In this study diversity of cultivable bacteria and their exopolysaccharide production potential were investigated from the water and sediment samples of coastal site of ALang. The studied ten samples represented diversity in $\mathrm{pH}$, conductivity, salinity and TDS, in the range of 7.25 to $8.92,9.4$ to $76.8 \mathrm{mS}, 3570$ to $35100 \mathrm{mg} / \mathrm{L}$ and 15120 to $53100 \mathrm{mg} / \mathrm{L}$ respectively. Total 141 bacteria were isolated from the collected ten samples, from which 105 were gram positive and 36 were gram negative in nature. Amongst the isolates 33\% were able to produce variety of pigments. The diversity indices, including Shannon-Wiener index (H'), Richness, and Evenness Indices based on the metabolic characteristics of the organisms were calculated. The isolates were characterized morphologically and biochemically. Identification of 41 isolates was confirmed by $16 \mathrm{~S}$ rRNA gene sequencing. They represented 22 genera and various species of these genera. The bacterial isolates were able to grow in the range of 3-25\% $\mathrm{NaCl}$ concentrations. When 141 cultures were grown in liquid medium, the viscosity of the medium ranged between $9.20 \times 10^{-6}$ to $2.09 \times 10^{-4} \mathrm{~m} . \mathrm{pa} . \mathrm{s}^{-1}$. The EPS yield in terms of dry weight also ranged from 0.76 to $10.7 \mathrm{~g} / \mathrm{L}$.
\end{abstract}

Keywords: Alang, coastal, diversity indices, exopolysaccharide, phylogeny, pigment

\section{INTRODUCTION}

India has the coastline of 7516 kilometers, out of this Gujarat state contributes about 21\% ( 1600 kilometers) of the coastline (Venkatraman, 2008; Parikh et al., 2012). The coastal region of the Bhavnagar is a center for varied economic activities like salt production, mining, fishing, ship building and breaking. Alang is the largest ship breaking yard in the world and is a census town of Bhavnagar district. Its economical importance with regards to its salt production value and ship breaking process makes it a valuable site for the microbiological studies. Studied saline sites of India are Sambhar salt lake, Rajasthan (Sahay et al., 2012), Coastal regions of Gujarat, (Dave and Desai, 2006), Little Rann of Kutchh, Gujarat (Thomas et al., 2012), Tamilnadu, Andhra Pradesh (Kumari et al., 2013), Maharashtra (Deshmukh et al., 2011), Orissa (Bal et al., 2009), and West Bengal (Das et al., 2012). Some of the coastlines studied worldwide are the Great Salt Lake (Utah, USA), the Dead Sea (Israel), the alkaline brines of Wadi Natrun (Egypt), and Lake Magadi (Kenya) (Nanjani and Soni, 2012). These habitats represent extreme conditions of high salinity, high $\mathrm{pH}$, low oxygen conditions and different range of temperature values and are inhabited by halotolerant as well as halophilic microorganisms (Moreno et al., 2013). Members of the domain bacteria are of special interest to scientists, as they play an important role in saline as well as hypersaline environments and have the potential to produce compounds of industrial interest, one of these compounds is the exopolysaccharide (EPS) (Antoin et al., 2000; Hedi et al., 2014). Novel EPS with better characteristics can be developed from the isolates of such ecosystem than those of the existing one (Bejar et al., 1998). EPS produced by microorganisms has a number of applications in pharma, food, petroleum and other industries (Sutherland, 1990). Because of their unique properties they can be used as coagulants, thickening agents, binder, emulsifiers, stabilizers, lubricants and gelling agents (Sutherland, 1997). EPS have been reported to increase the viscosity of solution at low $\mathrm{pH}$ values, as a good surface active agent for heavy metal remediation and provides gluing properties in soil aggregation (Kalpan et al., 1987; Nisha et al., 2007). The saline site of Alang, Bhavnagar, is less explored_ in the bacterial diversity study and particularly for the EPS production from such organisms, thus the purpose was to analyze the physicochemical properties of the collected samples, elucidation of the culturable diversity of marine bacteria isolated from the Alang coastline and their potential to produce EPS.

\section{MATERIALS AND METHODS}

\section{Sampling site and sample collection}

Ten different samples comprising five sea water ( sample 1-5) and five sediments ( sample 6-10) were collected for the study from the different sites (about $50 \mathrm{~m}$ distance between two points) of the coastal region of Alang, Bhavnagar, having area of $160 \times 10 \mathrm{~m}$ (latitude $21^{\circ} 36^{\prime} \mathrm{N}$, longitude $72^{\circ} 18^{\prime} \mathrm{E}$ ). The surface water samples were collected directly into sterile bottles while the sediments $(0.5-1.0 \mathrm{~m}$ depths from water surface) were collected in sterile plastic bags.

\section{Physico-chemical analysis of the sediment and water samples}

From the collected water samples, $\mathrm{pH}$ and conductivity were measured directly using a portable multimeter analyzer (Eutech, Singapore). Where as for the collected sediment samples, $10 \% \mathrm{w} / \mathrm{v}$ sediments were suspended in distilled water for all the analysis. Parameters like total solids (TS) and total dissolved solids (TDS) were determined using gravimetry method. Soluble chloride estimation was done by titration with $\mathrm{AgNO}_{3}, \mathrm{Ca}^{2+}$ and $\mathrm{Mg}^{2+}$ were measured using EDTA. Standard analytical procedures were followed for the determination of all the parameters (APHA, 1995).

\section{Isolation and characterization of marine bacteria}

Collected samples were serially diluted and spreaded on Zobell Marine Agar (ZMA), Zobell Marine Sea Water Agar (ZMSA), R2A Agar, Artificial Sea Water Agar (ASWA) with $0.5 \mathrm{~g} / \mathrm{L}$ peptone and $1.0 \mathrm{~g} / \mathrm{L}$ glucose, Nutrient Agar (NA) with five different concentrations of sodium chloride $(3,5,10,15$ and $20 \% \mathrm{w} / \mathrm{v})$ and Alang Sea Water Medium (ASWM) containing $0.5 \mathrm{~g} / \mathrm{L}$ peptone and $1.0 \mathrm{~g} / \mathrm{L}$ glucose in sea water. All the media constituents used in the study were acquired from Hi Media, India. All the plates were incubated at $30 \pm 2{ }^{\circ} \mathrm{C}$ for $48-72 \mathrm{~h}$ to grow bacteria. The viable bacterial count was determined in terms of Colony Forming Unit (CFU) and from apparently different colonies, organisms were purified and sub cultured in the respective medium (Bianchi et al., 1992). Isolates were preliminary identified on the basis of morphological and biochemical observations according to the methods described in the Bergey's manual of systematic bacteriology (Brenner et al., 2005; Vos et al., 2009). 


\section{Salt tolerance study}

Salt tolerance study of all the bacterial isolates was carried out using nutrient broth with increasing $\mathrm{NaCl}$ concentrations $(0-30 \%$ w/v $\mathrm{NaCl})$. In each tube containing $5.0 \mathrm{~mL}$ of the growth medium, $100 \mu \mathrm{L}$ of activated bacterial culture $\left(\mathrm{OD}_{620}=1.0\right)$ was inoculated. Growth was measured at $620 \mathrm{~nm}$ after $24 \mathrm{~h}, 48 \mathrm{~h}$ and $72 \mathrm{~h}$. Based on the salt tolerance potential all the isolates were categorized as non-halophiles, halotolerant, slight and moderate halophiles as described in The Prokaryotes (Oren, 2006).

\section{Diversity indices and statistical analysis}

Based on the phenotypic characteristics of the organisms, Shannon Weiner diversity index ( $\left.H^{\prime}\right)$, Richness $\left(\mathrm{R}_{\text {margalef }}, \mathrm{R}_{\text {menhinik) }}\right.$ and Evenness ( $\left.\mathrm{E}_{\text {Pielou }}\right)$ were calculated by the standard formula (Derry et al., 1998; Dave et al., 2002). The data of biochemical tests were applied to Principal Component Analysis (PCA) and Hierarchial Cluster Analysis (HCA) using the statistical package (IBM SPSS Statistics, version 20, 2011) for windows (Soni et al., 2002).

\section{Molecular identification by $16 \mathrm{~S}$ rRNA gene sequencing and phylogenetic analysis}

The taxonomic identity of the selected bacterial isolates was confirmed by $16 \mathrm{~S}$ rRNA gene sequencing along with the biochemical tests. The 16S rRNA sequences of the bacteria were submitted to the GenBank and accession numbers were obtained. All sequences were aligned with a multiple sequence alignment and phylogenetic tree of the isolates was constructed by the neighbor joining analysis using Kimura's two-parameter model using MEGA 6.0 (Kimura, 1980; Saitou and Nei, 1987).

\section{Screening of EPS producers}

Bacterial isolates that produced high mucoid colonies were selected for further screening and their EPS production ability was checked using EPS broth medium (Atlas, 1993).

\section{EPS production and extraction}

The growth of various isolates was harvested in sterilized normal saline, cell count was performed spectrophotometrically at $600 \mathrm{~nm}$ and $10 \%(\mathrm{v} / \mathrm{v})$ inoculum consisting $1 \times 10^{8}$ cells $/ \mathrm{mL}$ was inoculated into $250 \mathrm{~mL}$ capacity Erlenmeyer flask containing $100 \mathrm{~mL}$ EPS broth medium consisting of $(\mathrm{g} / \mathrm{L})$ : casein hydrolysate, 15; sodium acetate, 12, $\mathrm{K}_{2} \mathrm{HPO}_{4}, 10$; yeast extract, 5; L--Cystine, 0.5; NaOH, 30 and sucrose, 50 . The flasks were incubated on orbital shaker (Newtronics, India) rotating at $150 \mathrm{rpm}$ at $30 \pm 2{ }^{\circ} \mathrm{C}$. At different time intervals the viscosity of the medium was studied. Extraction of EPS was carried out using chilled acetone in 1:3 ratio (Watanabe et al., 1999), and was kept at $4{ }^{\circ} \mathrm{C}$ for overnight Precipitated EPS was separated by centrifugation at 10,000 $\mathrm{g}$ and wet weight of EPS was recorded (Ashok $\boldsymbol{e t}$ al., 2011; Razack $\boldsymbol{e t}$ al., 2013). The separated EPS was dried at $65{ }^{\circ} \mathrm{C}$ in oven to get the constant dry weight.

\section{RESULTS AND DISCUSSION}

\section{Physico-chemical characterization of samples}

The physico-chemical characteristics of the samples are represented in Table 1 The $\mathrm{pH}$ of the samples ranged from 7.25 to 8.92 obviously due to the presence of dissolved salts in marine water. The temperature at the time of sample collection was $34 \pm 4{ }^{\circ} \mathrm{C}$. The conductivity of the samples ranged from $9.4 \mathrm{mS}$ to $76.8 \mathrm{mS}$ The sediment samples showed salinity ranging from $3570-18400 \mathrm{mg} / \mathrm{L}$, whereas, water samples showed the salinity ranging from $21950-35100 \mathrm{mg} / \mathrm{L}$. The chloride $\left(\mathrm{Cl}^{-}\right)$concentration ranged from $2170-10250 \mathrm{mg} / \mathrm{L}$ and $12053-22688 \mathrm{mg} / \mathrm{L}$ for sediment samples and water samples respectively. $\mathrm{NaCl}$ concentration of sediment samples ranged from 2095.5-16912.5 mg/L and that of water samples ranged from $866.25-2179.55 \mathrm{mg} / \mathrm{L}$. Hardness of the samples in terms of $\mathrm{Ca}^{2+}$ and $\mathrm{Mg}^{2+}$ was found in the range from $78-758 \mathrm{mg} / \mathrm{L}$ and $320-1200 \mathrm{mg} / \mathrm{L}$ respectively. Samples had TDS values between $15120-53100 \mathrm{mg} / \mathrm{L}$. The overall composition of the samples differed depending on the site of sampling. Physico-chemical analysis of the liquid samples showed minor $\mathrm{pH}$ variations as compared to solid samples. However, conductivity, TS, salinity, $\mathrm{Cl}^{-}, \mathrm{Mg}^{2+}, \mathrm{Ca}^{2+}$ content of water sample showed variation of $1.73,1.72,1.80,1.88,1.51,1.66$ fold respectively. Where as conductivity, TS, salinity, $\mathrm{Cl}^{-}, \mathrm{Mg}^{2+}, \mathrm{Ca}^{2+}$ content of sediment sample showed variation of $3.98,2.41,4.74,4.72,5.48,1.62$ fold respectively, which were analyzed by preparing the $10 \%$ samples. However, the results presented here are of one particular day and hence the variation was due to the different sites that too within $160 \times 10 \mathrm{~m}$ are and not due to the season. Sediment systems were more diverse as compared to water samples collected from the same place. As per the reported results of the coastal region of Alang and South Saurashtra coastal stretch of Gujarat, $\mathrm{pH}$ ranges from 7.9 to 8.39 (Bhadeja and Kundu, 2011).

Table 1 Physico-chemical analysis of the samples

\begin{tabular}{|c|c|c|c|c|c|c|c|c|c|}
\hline Samples & $\mathrm{pH}$ & $\begin{array}{l}\text { Conductivity } \\
(\mathrm{mS})\end{array}$ & $\mathrm{TS}(\mathrm{mg} / \mathrm{L})$ & TDS (mg/L) & $\begin{array}{l}\text { Salinity } \\
(\mathrm{mg} / \mathrm{L})\end{array}$ & $\begin{array}{c}\mathrm{Cl}^{-} \\
(\mathrm{mg} / \mathrm{L})\end{array}$ & $\mathrm{Ca}^{2+}(\mathrm{mg} / \mathrm{L})$ & $\begin{array}{c}\mathrm{Mg}^{2+} \\
(\mathrm{mg} / \mathrm{L})\end{array}$ & $\mathrm{NaCl}(\mathrm{mg} / \mathrm{L})$ \\
\hline 1 & 7.35 & 58.92 & 44450 & 44350 & 30240 & 21979 & 608 & 880 & 36265.35 \\
\hline 2 & 7.25 & 69.55 & 48814 & 48750 & 35100 & 22688 & 588 & 1050 & 37435.2 \\
\hline 3 & 7.45 & 76.8 & 53232 & 53100 & 19775 & 12053 & 758 & 1200 & 19887.45 \\
\hline 4 & 7.56 & 48.39 & 37592 & 37520 & 27360 & 14889 & 488 & 850 & 24566.85 \\
\hline 5 & 7.25 & 44.15 & 30896 & 30800 & 21950 & 15598 & 456 & 790 & 25736.7 \\
\hline 6 & 8.62 & 12.06 & 30400 & 29800 & 3570 & 2170 & 318 & 480 & 2095.5 \\
\hline 7 & 8.92 & 9.4 & 26350 & 25900 & 4090 & 3210 & 119 & 369 & 5296.5 \\
\hline 8 & 8.75 & 11.8 & 37250 & 36500 & 6390 & 4180 & 428 & 520 & 6732 \\
\hline 9 & 8.33 & 37.5 & 29050 & 28500 & 18400 & 10250 & 268 & 460 & 16912.5 \\
\hline 10 & 8.01 & 14.19 & 15420 & 15120 & 8370 & 5250 & 78 & 320 & 8662.5 \\
\hline
\end{tabular}

1-5 water and 6-10 sediment samples

\section{Morphological and physiological characterization of isolates}

Initially sample number 4,6 and 8 were studied on all the 10 culture media described above to select the most suitable medium for the study of all the samples. Detail of the bacterial viable count of these samples is given in Table 2a. Amongst all the media used, the highest bacterial count was obtained on ZMA, and Nutrient agar with $3 \% \mathrm{NaCl}$ concentrations, respectively, hence further isolation study from all the samples was carried out with ZMA and NA (both with $3 \% \mathrm{NaCl}$ ) and the $\mathrm{CFU}$ of bacteria on ZMA in comparison with NA is listed in Table $2 \mathrm{~b}$. The highest $\mathrm{CFU} / \mathrm{mL}$ of culturable bacteria was found as $134 \times 10^{6}$ in the sample number 8 on ZMA; whereas, the lowest CFU/mL of culturable bacteria was found as $0.5 \times 10^{6}$ in the sample number 5 on NA. ZMA proved to be the medium of choice for the isolation of the organisms from such saline habitat. As can be seen from the results some of the bacteria grew even in the presence of $20 \% \mathrm{NaCl}$ concentration in NA(Table 2a), indicated the presence of helophilic or helotolerant organisms.

Table 2a Total bacterial count of three samples on all media studied

Total viable count $\left(\times 10^{6} \mathrm{CFU} / \mathrm{ml}\right)$

\begin{tabular}{|c|c|c|c|c|c|c|c|c|c|c|}
\hline \multirow[t]{2}{*}{ Sample } & \multicolumn{10}{|c|}{ Medium } \\
\hline & ZMA & ZMSA & $\mathrm{R} 2 \mathrm{~A}$ & ASWA & ASWM & $\begin{array}{l}\text { NA } \\
(3 \%)\end{array}$ & $\begin{array}{c}\text { NA } \\
(5 \%)\end{array}$ & $\begin{array}{c}\text { NA } \\
(10 \%)\end{array}$ & $\begin{array}{c}\text { NA } \\
(15 \%)\end{array}$ & $\begin{array}{c}\text { NA } \\
(20 \%)\end{array}$ \\
\hline 4 & 2.2 & 0.68 & 0.021 & 0.024 & 0.028 & 0.8 & 0.74 & $2 *$ & $0.012^{*}$ & $0.01 *$ \\
\hline 6 & 84 & 62 & 0.044 & 0.05 & 0.044 & 24 & 0.88 & $4.7^{*}$ & $0.03^{*}$ & $0.024 *$ \\
\hline 8 & 134 & 40 & 0.052 & 0.062 & 0.088 & 32 & 1.2 & $7.0^{*}$ & $0.021^{*}$ & $0.026^{*}$ \\
\hline
\end{tabular}

*=_x $10^{3} \mathrm{CFU} / \mathrm{mL}$ 
Table 2b The viable count of bacteria on ZMA in comparison with NA.

Medium Total viable count $\left(\times 10^{6} \mathrm{CFU} / \mathrm{mL}\right)$

\begin{tabular}{|c|c|c|c|c|c|c|c|c|c|c|}
\hline & \multicolumn{10}{|c|}{ Sample number } \\
\hline & 1 & 2 & 3 & 4 & 5 & 6 & 7 & 8 & 9 & 10 \\
\hline ZMA & 6.8 & 3.1 & 4.4 & 2.2 & 1.2 & 84 & 40 & 134 & 12 & 7 \\
\hline NA & 3.2 & 2.5 & 1.1 & 0.8 & 0.5 & 24 & 13 & 32 & 40 & 20 \\
\hline
\end{tabular}

Morphologically different 141 bacterial isolates were isolated from the collected samples. The colony size of the isolates ranged from 0.4 to $2.8 \mathrm{~mm}$. Out of 141 isolates, 105 were gram positive and 32 isolates were gram negative and 4 were actinomycetes. In case of gram positive isolates, cocci were large in numbers as compared to gram positive rods. Out of 105 gram positive isolates, $55 \%$ were cocci, $41 \%$ were gram positive rods. Amongst 141 isolates, $23 \%$ of the isolates were able to produce varieties of pigments while the rest of them gave nonpigmented colonies. Pigmented colonies showed white, creamish white, yellow, red, orange, pink and bluish green pigments. Yellow pigmented colonies showed variation in shades like golden yellow, lemon yellow and light yellow. Comparison of pigmented and non-pigmented colony from all the samples studied is shown in Fig.1a. Sample 8 showed the highest percent of pigmented isolates and sample 10 showed the lowest percent of pigmented isolates. Light yellow pigments were the highest in number where as bluish green was the lowest. Gram positive cocci produced variety of pigments as compared to gram positive bacilli and gram negative rods (Fig. 1b).

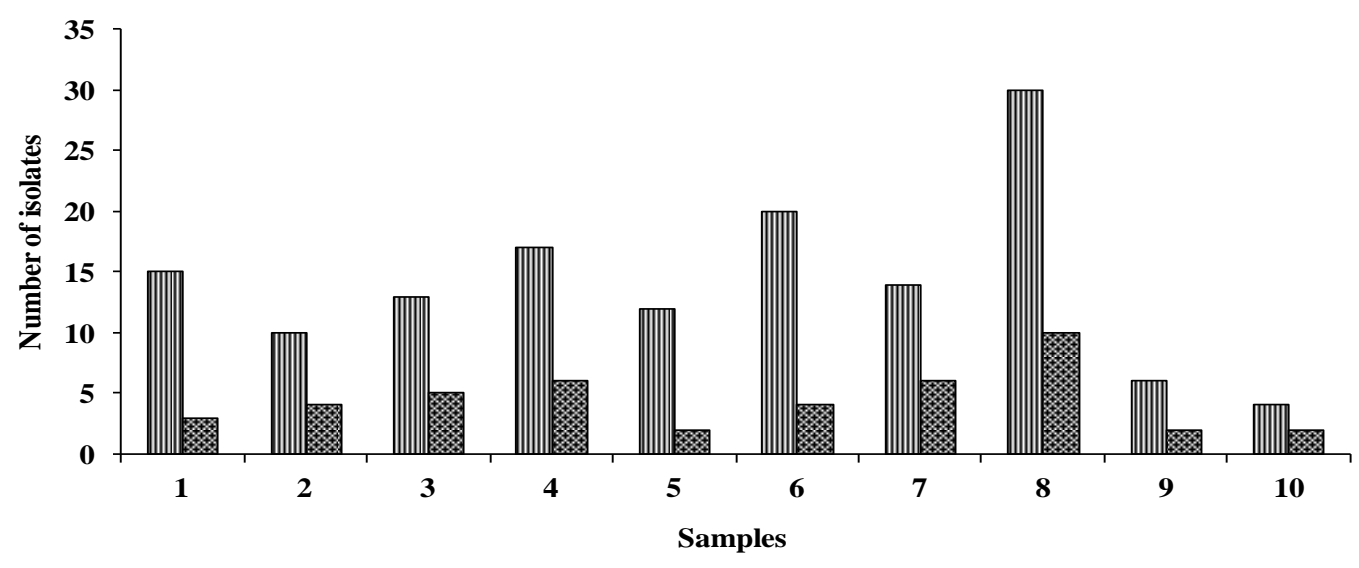

mumber of isolates Number of pigmented isolates

Figure 1a Comparison of pigmented bacteria with the total number of isolates in different samples

Amongst 141 bacterial isolates, 132 isolates were able to grow up to $5 \%$ of $\mathrm{NaCl}$ concentration, 105 isolates up to $10 \%, 27$ isolates up to $15 \%$ and only 5 isolates showed growth up to $20 \%$ of salt concentration. From these five, only two were able to grow up to $25 \%$ of $\mathrm{NaCl}$ concentration. None of them showed any growth at $30 \% \mathrm{w} / \mathrm{v}$ of salt concentration. As the salt concentration was increased the growth of the organisms was found to be decreased into the medium. Organisms showed intense growth at low salt concentrations (3-5\%) within 24-48 h, moderate growth at $10 \%$ of $\mathrm{NaCl}$ concentration and scanty growth at high $\mathrm{NaCl}$ concentration (15-25\%) after 2-3 d of incubation period. There are some reports on the diversity study of marine salterns near Bhavnagar and from the coastal region of Dwarka-Veraval. According to that the microbial diversity and growth of the microorganisms found to decrease with higher salt concentration (Dave and Desai, 2006; Nanjani and Soni, 2012). Gram positive bacteria were more in numbers between $10-15 \%$ of $\mathrm{NaCl}$ concentrations; whereas, gram negative isolates showed dominance between $20-25 \%$ of $\mathrm{NaCl}$ concentrations. The comparable results are also obtained in a study of isolation of halotolerant and halophilic bacteria (Purohit et al., 2015).

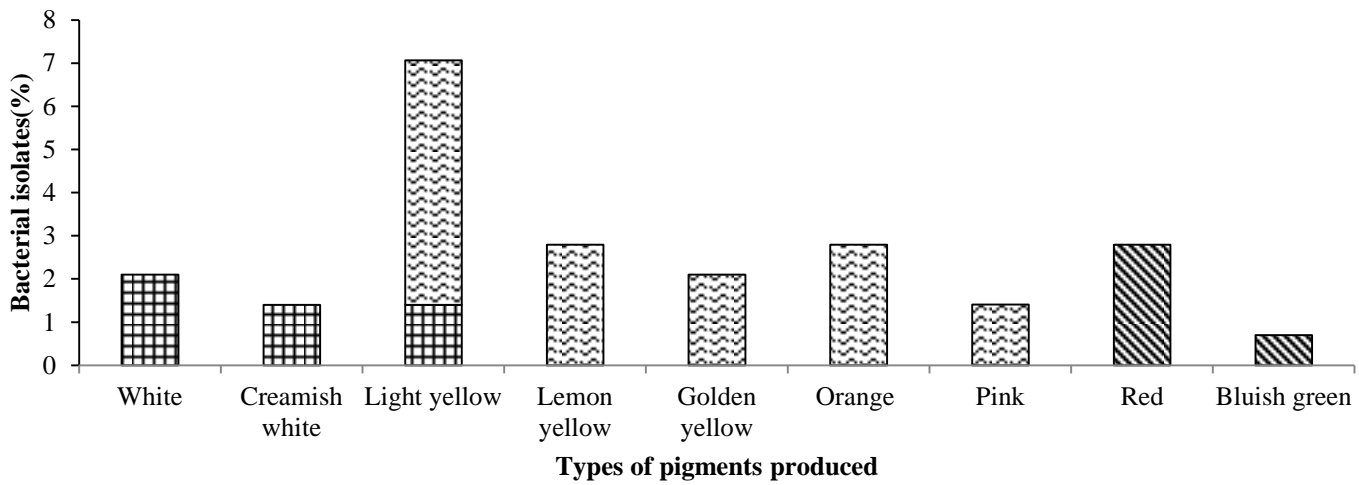

$\boxplus$ Bacillus $\mathbf{\square C o c c i} \boldsymbol{\otimes}$ Short rods

Figure 1b Dominance of the group of bacteria, in particular pigment production

\section{Diversity indices}

The results of various diversity indices are presented in Table 3. As can be seen for all the samples, Shannon Weiner index (H') varied from 1.043 to 2.86 Sample 3, 6 and 8 had H'values above 2.5. Sample 1, 2 and 4 had H' values above 2, forming another group. The rest of the samples showing H' index values above 1 were grouped separately. Evenness values ranged from 0.752 to 1.209 . Richness, $\mathrm{R}_{\text {margalef }}$ ranged from 0.333 to 1.140 and $\mathrm{R}_{\text {menhinik }}$ ranged from 0.0422 to 0.0848 . Based on all the four indices, it can be concluded that the sample number 10 had overall low diversity where as sample 8 showed high diversity, high richness and high evenness. Moreover, it represented the most diverse bacteria communities capable of growing with a wide range of salt concentrations and producing variety of pigments could be the reason for its high diversity value.
The lowest dissolved solids, $\mathrm{Ca}^{2+}$ and $\mathrm{Mg}^{2+}$ content could be responsible for low diversity and evenness of the organisms in sample 10. However, there are some samples with high diversity and richness, but low evenness and vise versa. Haque et al., (2004) have reported that the samples, which shows similar diversity values may incorporate low evenness and the high richness or consist of high evenness and low richness. In some cases the sample shows all three parameters high or low simultaneously. Therefore, one should consider the diversity, richness and evenness collectively during diversity studies. 
Table 3 Diversity indices for bacterial populations from various samples based on their physiological profile

\begin{tabular}{lcccc}
\hline \multirow{2}{*}{$\begin{array}{l}\text { Sample } \\
\text { no. }\end{array}$} & Shannon Diversity $\left(\mathrm{H}^{\prime}\right)$ & \multicolumn{2}{c}{ Richness } & Evenness \\
\cline { 3 - 4 } & & $\mathrm{R}_{\text {Margalef }}$ & $\mathrm{R}_{\text {Menhinick }}$ & $\mathrm{E}_{\text {Pielou }}$ \\
\hline 1 & 2.47 & 1.11 & 0.0848 & 0.994 \\
2 & 2.15 & 0.723 & 0.0632 & 1.034 \\
3 & 2.51 & 0.696 & 0.0527 & 1.209 \\
4 & 2.09 & 0.844 & 0.0789 & 0.952 \\
5 & 1.54 & 0.418 & 0.0422 & 0.96 \\
6 & 2.73 & 0.87 & 0.0567 & 1.189 \\
7 & 1.41 & 0.549 & 0.0632 & 0.787 \\
8 & 2.86 & 1.140 & 0.0675 & 1.11 \\
9 & 1.55 & 0.537 & 0.0572 & 0.866 \\
10 & 1.043 & 0.333 & 0.0447 & 0.752 \\
\hline
\end{tabular}

Principal component and Hierarchical Cluster Analysis

PCA based on different biochemical tests was able to group the 39 bacterial isolates on the basis of the similarities and differences in their metabolic behaviour. Results are shown in the Fig. $2 \mathrm{a}$ and $2 \mathrm{~b}$. Total 7 principal components were extracted. PC1 and PC2 explained $18.84 \%$ and $14.19 \%$ diversity, respectively, of the total variance present in the original data. Bacterial isolates formed different groups in PCA, among these groups isolates E2 and E3, SR31 and SR 103, SR 49, SR52 and KD, SR 24, K5 and K8, SR 40 and SR 47 were closely placed because of their similar metabolic behaviour. The Hierarchical Cluster Analysis represents the similar observations as PCA. It shows the leas distance between the isolates explained above. Isolate SR 104 placed distinctly from the rest of the isolates in PCA. It could be due to its distinct metabolic properties . Isolates also showed a wide diversity With respect to fermentation of 21 sugars studied(Results are not shown).

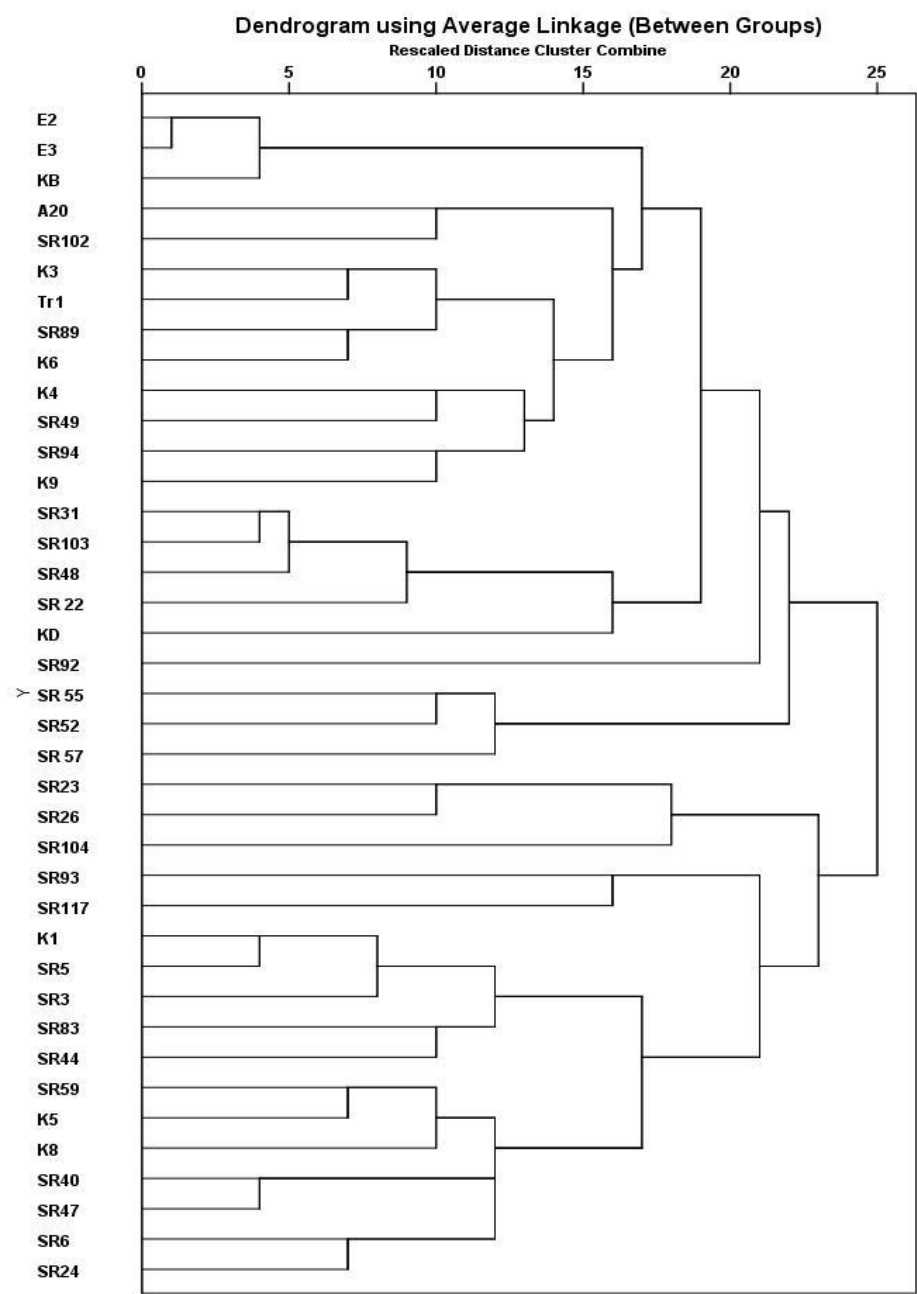

Figure 2a The Dendogram showing relationship amongst bacterial isolates using Hierarchical cluster analysis of biochemical test data

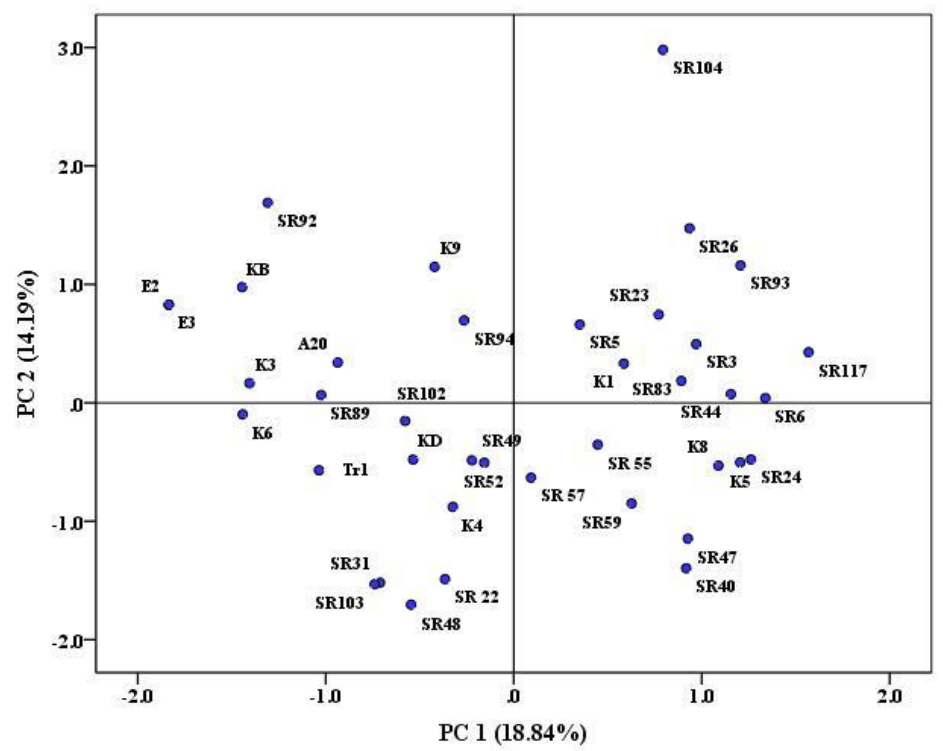

Figure 2b PCA of biochemical tests of 39 isolates at their optimal incubation time

\section{Phylogenetic analysis of the isolates}

Based on the results of 16S rRNA partial gene analysis selected isolates represented 22 genera and various species of these genera. Thus, it is obvious to have morphological, metabolical and EPS production diversity. Phylogenetic analysis of the isolates showed that most of them belonged to the phylum Firmicutes, followed by gamma-Proteobacteria. Gram positive bacteria of genera Bacillus, Exiguobacterium, Micrococcus, Arthrobacter, Kocurea, Planococcus, Cellulosimicrobium, Actinotalea and some of the Gram negative isolates related to genera Pseudomonas, Enterobacter, Pontibacter, Sinorhizobium, Mesorhizobium and Dyadobacter were cultured from the Alang ecosystem. Gamma-Proteobacteria included isolates of Halomonas and Marinobacter sp. The studied samples were from the same plot at the Alang coastal line, but they are from 10 different sites, which could be the reason of great diversity observed in the bacterial isolates. Members of the genus Bacillus, Exiguobacterium Micrococcus, Arthrobacter, Planococcus, Cellulosimicrobium, Pseudomonas and Enterobacter have also been isolated from other saline environments, including Krishna Godavari basin (Bay of Bengal), Lonar Lake (Maharashtra) and coastal area of Tamilnadu (Jaynath et al., 2002; Kanekar et al., 2007; Devi et al., 2011). Based on the 16S rRNA gene analysis, evolutionary relationship between the cultivable microbes, isolated from the coastal region of Alang, Bhavnagar was studied using the neighbor- joining method (Fig. 3). The accession numbers are given in parentheses. Only bootstrap values are shown at nodes (based on 500 bootstrap resampling). The scale bar represents $1 \%$ divergence. Total 41 different microbial species were identified. The evolutionary distance is depicted by the length of the horizontal line. The branch point along the length of the horizontal line is the point of divergence of two microbial species. The outer, Paenibacillus polymyxa represents a distinct group with minimum evolution in relationship with the rest of the isolates. On the other hand, the significant divergence (2 to 3 step divergence) is observed among other microbes, including halotolerant Halomonas, chemoorganotrophs Salinicola salaries, aerobes Pseudomonas, anaerobes and facultative anaerobes Enterobacter. The community also contains some unique plant pathogens like Xanthomonas campestris. On the basis of this diversity study, it can be concluded that the selected site is highly enriched with the various types of microbes having divergent metabolic potential in spite of ship breaking activity at the site. 


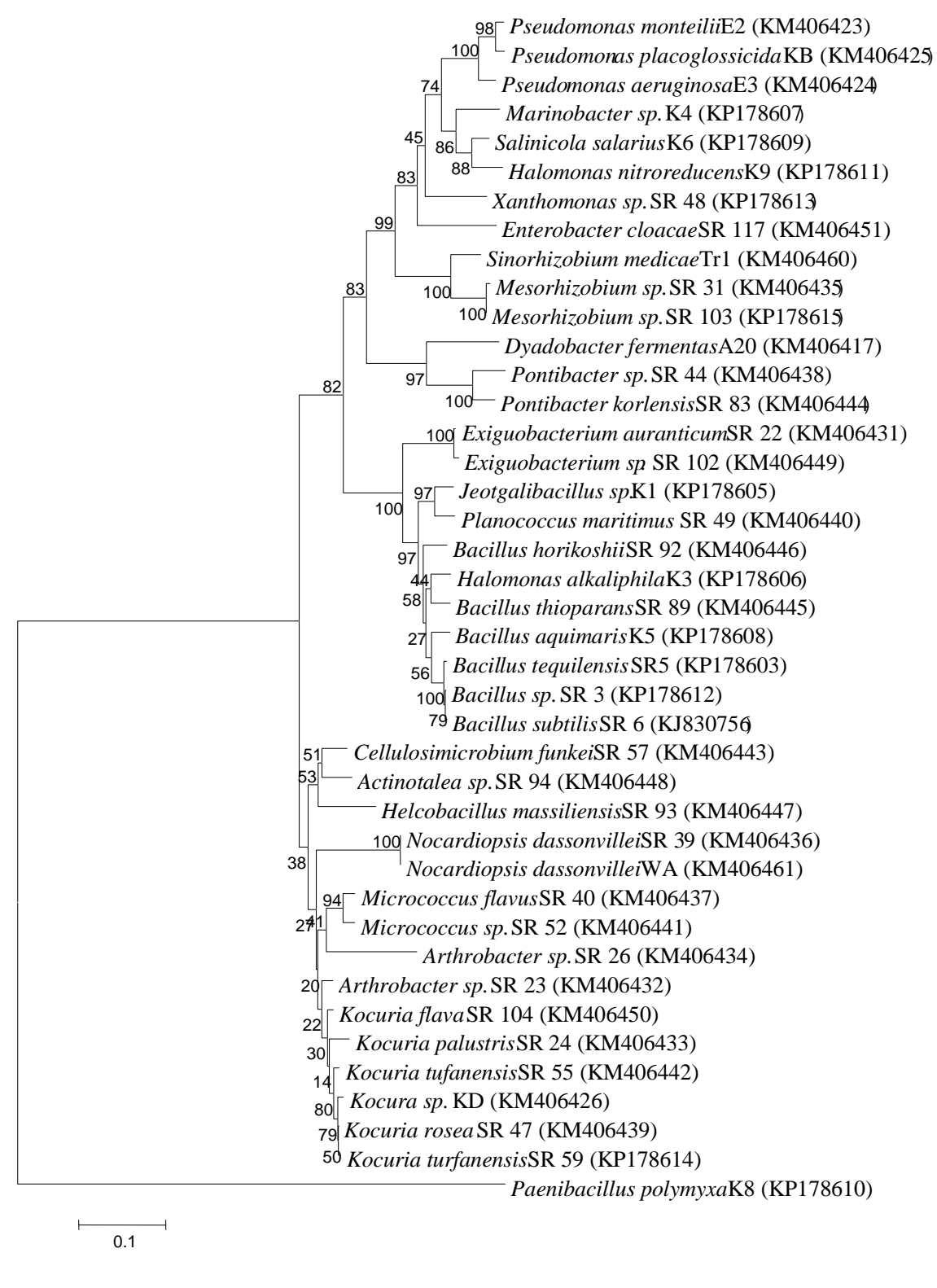

Figure 3 Neighbor joining phylogenetic tree of the 16S rRNA partial gene sequences of bacteria isolated from the coastal region of Alang, Bhavnagar

\section{Rheological properties and EPS production study}

Change in viscosity of the media was measured, in which EPS producers were grown and studied organisms showed quite a broad variation in viscosity. Out of 141 isolates 88 isolates showed variation in viscosity between $9.20 \times 10^{-6}$ to $1.6 \times 10^{-5} \mathrm{~m} \cdot \mathrm{pa} . \mathrm{s}^{-1}, 28$ isolates showed it between $1.7 \times 10^{-5}$ to $2.6 \times 10^{-5} \mathrm{~m} \cdot \mathrm{pa} . \mathrm{s}^{-1}$ and for remaining 25 isolates it was $2.7 \times 10^{-5}$ to $2.09 \times 10^{-4} \mathrm{~m} . \mathrm{pa} . \mathrm{s}^{-1}$ when cultivated in EPS broth medium. Isolate SR5, SR6, SR40, SR48, SR55, SR83, SR117, Tr1 and K9 were found to be high EPS producers. In this study EPS production was observed in the range from $0.76 \mathrm{~g} / \mathrm{L}$ to $10.7 \mathrm{~g} / \mathrm{L}$. The observed variation was obviously due to the diverse variety of the species as well as genus. EPS production yield by Halomonas nitroreducens was $0.76 \mathrm{~g} / \mathrm{L}$, Sinorhizobium medicae was $3.44 \mathrm{~g} / \mathrm{L}$, Enterobacter cloacae was $4.2 \mathrm{~g} / \mathrm{L}$, Xanthonas sp. was $6.48 \mathrm{~g} / \mathrm{L}$, Kocurea turfenensis was $7.1 \mathrm{~g} / \mathrm{L}$, Micrococcus flavus was $8.0 \mathrm{~g} / \mathrm{L}$, Bacillus tequilensis was $8.8 \mathrm{~g} / \mathrm{L}$, Pontibacter korlensis was $9.8 \mathrm{~g} / \mathrm{L}$, and Bacillus subtilis was $10.7 \mathrm{~g} / \mathrm{L}$. Reported range of EPS production from halotolerant organism is $0.16 \mathrm{~g} / \mathrm{L}$ to $3.0 \mathrm{~g} / \mathrm{L}$. Halomonas ventosa, Bacillus licheniformis, Halomonas anticariensis are moderate halophiles showing EPS yield $0.29 \mathrm{~g} / \mathrm{L}$, $0.165 \mathrm{~g} / \mathrm{L}$ and $0.5 \mathrm{~g} / \mathrm{L}$ respectively (Bejar et al., 2006; Maugeri et al., 2002). As halotolerant organisms survive in extreme conditions, they may be used for production of biopolymers, halophilic enzymes, compatible solutes and in the bioremediation process (Ventosa et al., 1998; Margesin and Schinner, 2001; Mellado and Ventosa, 2003).

\section{CONCLUSIONS}

The site of Alang could be a good source of culturable bacterial diversity as different halotolerant and moderate halophilic bacteria were isolated from it. To the best of the authors' knowledge, the presence of the organisms, namely Pontibacter korlensis, Kocurea tirfenensis, Actinotalea, Sinorhizobium sp., Cellulosimicrobium funkei, Helcobacillus massiliensis and Dyadobacter fermentas from the coastal area of Alang, Bhavnagar is the first report. The significant finding was that many of these isolates grew in the presence of as high as $3-10 \% \mathrm{NaCl}$ concentrations and some grew even in $20-25 \% \mathrm{NaCl}$, more over they produce a significant amount of EPS. EPS production by Kocurea turfenensis (SR55) and Pontibacter korlensis (SR 83) might be the new finding of this study. EPS produced by these organisms can be explored for various economical uses as it may have distinct properties with biotechnological applications.

Acknowledgement: We are thankful to the all teaching and non teaching staff of our department for their support and to the Department of Science and Technology (DST), New Delhi for providing the INSPIRE Fellowship to Kinjal Upadhyay.

\section{REFERENCES}

Antoin, J., Rossello, M., Rodriguez Valera, F., \& Amann, R. (2000). Extremely halophilic bacteria in crystallizer ponds from solar salterns. Applied and Environmental Microbiology, http://dx.doi.org/10.1128/aem.66.7.3052-3057.2000
66 , 3052-3057. 
APHA. (1995). Standard Methods for the Examinations of Water and Wastewater, $19^{\text {th }}$ edn, American Public Health Association, Washington DC, USA.

Ashok, M., Thangavel, K., \& Anandapandian, K. (2011). Production and characterization of exopolysaccharides (EPS) from biofilm forming marine bacterium, Brazilian Archieves of Biology and Technology, 54, 259-265. http://dx.doi.org/10.1590/S1516-89132011000200006

Atlas, RM. (1993). Handbook of Microbiological Media, Parks LC, (ed.) CRC Press Inc., Bocaraton, London.

Bal, S., Mishra, R., Rath, B., Sahu, H., \& Thatoi, H.(2009). Characterization and extracellular enzyme activity of predominant marine Bacillus spp. isolated from sea water of Orissa Coast, India, Malaysian Journal of Microbiology, 5, 87-93.

Bejar, V., Liamas, I., Calvo, C., \& Quesada, E. (1998). Characterization of exopolysaccharides produced by 19 halophilic strains of the species Halomona eurihalina, Journal of Biotechnoogy, 61, 135-141. http://dx.doi.org/10.1016/s0168-1656(98)00024-8

Bejar, M., Liamas, I., Arias, S., Bressollier, R., Tallon, MC., \& Quesada, E. (2006). EPS produced by the recently described halophilic bacteria Halomonas ventosa and Halomonas anticariensis, Science Direct, Research in Microbiology, 157(9), 827-835. http://dx.doi.org/10.1016/j.resmic.2006.06.004

Bhadeja, P., \& Kundu, R. (2011). Status of the seawater quality at few industrially important coasts of Gujarat (India) off Arabian Sea. Indian Journal of Geo-Marine Sciences, 41(1), 90-97.

Bianchi, M., Perfettini, J., \& Bianchi, A. (1992). Marine heterotrophic bacteria associated with enrichment culture of nitrifying bacteria planned for closed aquaculture systems, Aquatic Living Resources, 5, 137-144. http://dx.doi.org/10.1051/alr:1992014

Brenner, D. J., Krieg, N. R., \& Staley, J. T. (2005). Bergey's Manual of Systematic Bacteriology, vol 2 The Proteobacteria, Part B The Gammaproteobacteria, Springer, USA.

Das, S., Mukherjee, I., Sudarshan, M., Sinha, T., Thakur, A., \& Raychaudhuri, S. (2012). Bacterial isolates of marine coast as commercial producer of protease, Online Journal of Biological Sciences, 12(3), 96-107. http://dx.doi.org/10.3844/ojbsci.2012.96.107

Dave, S. R.,\& Desai, H. B. (2006). Microbial diversity at marine salterns near Bhavnagar, Gujarat, India, Current Science, 90(4), 497-500.

Dave, S. R., Tipre, D. R., \& Gajjar, V. (2002). Fungal diversity in extreme environments of Malanjkhand copper mine, Asian Journal of Microbiology, Biotechnology and Environmental Sciences, 4(3), 367-373.

Derry, A. M., Staddon, W. J., \& Trevors, J. T. (1998). Functional diversity and community structure of microorganisms in uncontaminated and creosotecontaminated soils as determined by sole carbon-source-utilization, World Journal of Microbiology and Biotechnology, 14, 571- 578 . http://dx.doi.org/10.1023/a:1008812821516

Deshmukh, K., Pathak, A., \& Karuppayil, M. (2011). Bacterial diversity of Lonar soda lake of India, Indian Journal of Microbiology, 51(1), 107-111. http://dx.doi.org/10.1007/s12088-011-0159-5

Devi, N. K.. A., Rajendran, R., \& Sundaram, S. K. (2011). Isolation and characterization of bioactive compounds from marine bacteria, Indian Journal of Natural Products and Resources, 2(1), 59-64.

Haque, N. A., Soni, H. P., \& Dave, S. R. (2004). Soil microbial diversity with reference to utilization patterns of carbon and nitrogen sources. In: JAIN, P. C. (ed) Microbiology and Biotechnology for Sustainable Development, CBS Publishers and Distributors, New Delhi, pp 214-224.

Hedi, A., Essghaier, B., Cayol, J., Fardeau, M., \& Sadfii, N. (2014). Prokaryotic biodiversity of halophilic microorganisms isolated from Sehline Sebkha Salt Lake (Tunisia), African Journal of Microbiology Research, 8(4), 355-367. http://dx.doi.org/10.5897/ajmr12.1087

Jayanath, K., Jayasekaran, G., \& Jeyashkila, R. (2002). Isolation of marine bacteria antagonistic to human pathogens, Indian Journal of Marine Sciences, 31(1), 39-44.

Kalpan, D., Christian, D., \& Arod, S. (1987). Chelating properties of extracellular polysaccharides from Chlorella sp, Applied and Environmental Microbiology, 53, 2953-2956.

Kanekar, P., Joshi, A., Kelkar, A., Borgave, S., \& Sarnaik, S. (2007). Alkaline Lonar Lake, India-a treasure of alkaliphilic and halophilic bacteria, Proceedings of Taal the $12^{\text {th }}$ World Lake Conference, Jaipur, India, pp 1765-1774.

Kimura, M. (1980). A simple method for estimating evolutionary rates of base substitutions through comparative studies of nucleotide sequences, Journal of Molecular Evolution, 16(2), 111-120. http://dx.doi.org/10.1007/bf01731581

Kumari, C., Madhuri, R., \& Reddy, C. (2013). Antimicrobial potential of marine bacterial isolates from different Coastal regions of Andhra Pradesh and Tamil Nadu, India, International Journal of Current Microbiology and Applied Sciences, 2(10), 230-237.

Margesin, R., \& Schinner, F. (2001). Potential of halotolerant and halophilic microorganisms for biotechnology. Extremophiles 5(2), 73-83. http://dx.doi.org/10.1007/s007920100184

Maugeri, T., Gugliandolo, C., Caccamo, D., Panico, A., Lama, L., Gambacorta, A., \& Nicolaus, B. (2002). Halophilic thermotolerant Bacillus isolated from a marine hot spring able to produce a new exopolysaccharide, Biotechnology Letters, 24(7), 515-519. http://dx.doi.org/10.1023/a:1014891431233

Mellado, E., \& Ventosa, A. (2003). Biotechnological potential of moderately and extremely halophilic microorganisms. In: Barredo, J. (ed) Microorganisms for Health Care, Food and Enzyme Production. Kerala: Research Signpost, India, pp. 233-256.

Moreno, M., Perez, D., Teresa, M., \& Mellado, E. (2013). Halophilic bacteria as a source of novel hydrolytic enzymes, Life 3: 38-51. http://dx.doi.org/10.3390/life3010038

Nanjani, S. G., \& Soni, H. P. (2012). Diversity and EPS production potential of halotolerant bacteria from Veraval and Dwarka, IOSR Journal of Pharmacy and Biological Sciences, 2, 20-25. http://dx.doi.org/10.9790/3008-0222025

Nisha, R., Kaushik, A., \& Kaushik, C.( 2007). Effect of indigenous cyanobacterial application on structural stability and productivity of an organically poor semi-arid soil, Geoderma, 138, 49-56. http://dx.doi.org/10.1016/j.geoderma.2006.10.007

Oren, A. (2006). Life at high salt concentrations, In: Dworkin M, Falkow S, Rosenberg E, Schleifer K, Stackebrandt E. (eds), The Prokaryotes, $2^{\text {nd }}$ edn, vol 2, Springer-Verlag, Berlin, pp 263-282

Parikh, P., Panot, T., \& Desai, B. 2012. Seasonal variation in physico-chemica parameters and microfuana at Alang-sosiya ship breaking yard, Gujarat, India, Bionano Frontier, 5, 276-280.

Purohit, M. S., Tipre, D. R., Shah, M. B., \& Dave, S. R. (2015). Isolation of halotolerant and halophilic bacteria and screening of their poly enzyme potential, Indian Jornal of Geo-Marine Sciences. (in Press).

Razack, S., Velayatham, V., \& Thangavelu, V. (2013). Influence of various parameters on Exopolysachharide production from Bacillus subtilis, International Journal of Chemical Technology Research, 5, 2221-2228.

Sahay, H., Mahfooz, S., Singh, A. K., Singh, S., Kaushik, R., Saxena, A. K., \& Arora, D. K. (2012). Exploration and characterization of agriculturally and industrially important haloalkaliphilic bacteria from environmental samples of hypersaline Sambhar Lake, India, World Journal of Microbiology and Biotechnology, 28(11), 3207-3217. http://dx.doi.org/10.1007/s11274-012-1131-1 Saitou, N., \& Nei, M. (1987). The neighbor-joining method: a new method for reconstructing phylogenetic trees, Molecular Biology and Evolution, 4(4), 406425

Soni, H. P., Haque, N. A., \& Dave, S. R. (2002). Characterization of agricultura soils from semi-arid region on the basis of carbohydrate utilisation patterns of soil microbial communities. Asian Journal of Microbiology, Biotechnology and Environmental Sciences, 4 (3), 295-303.

Sutherland, I. (1990). Biotechnology of microbial exopolysachharides. In: Cambridge Studies in Biotechnology, 9, Cambridge University Press, Cambridge. pp 1-163.

Sutherland, I. (1997). Microbial exopolysachharides-structural subtleties and their consequences, Pure and Applied Chemistry, 69, 1911-1917. http://dx.doi.org/10.1351/pac199769091911

Thomas, M., Pal, K., Dey, R., Saxena, A., \& Dave, S. (2012). A novel haloarchaeal lineage widely distributed in the hypersaline marshy environment of Little and Great Rann of Kutch in India. Current Science, 103(9), 1078-1084.

Venkataraman, k. (2008). Coastal and Marine wetlands in India: Sengupta, M., Dalwani, R. (eds), Proceedings of Taal 2007, $12^{\text {th }}$ World Lake Conference, Jaipur, India, pp. 392-400.

Ventosa, A., Nieto, J., \& Oren, A. (1998). Biology of moderately halophilic aerobic bacteria, Microbiology and Molecular Biology Reviews, 62(2), 504-544

Vos, P. D., Garrity, G., Jones, D., Krieg, N. R., Ludwig, W., Rainey, F. A. Schleifer, K. H., \& Whitman, W. B. (2009).Bergey's Manual of Systematic Bacteriology, vol 3 The Firmicutes, Springer, USA.

Watanabe, M., Suzuki, Y., Sasaki, K., Nakashimmada, Y., \& Nishio, N. (1999). Floculating property of extracellular polymeric substance derived from a marine photosynthetic bacterium, Rhodovulvum sp, Journal of Biosciences and Bioengineering, 87, 625-629. http://dx.doi.org/10.1016/s1389-1723(99)80125-x 